\title{
PENGARUH PEMBERIAN RUMPUT RAJA (Pennisetum purpupoides) DAN TEBON JAGUNG TERHADAP PERFORMANS SAPI PERANAKAN ONGOLE (PO) BETINA
}

Heryanto*, K. Maaruf, S.S. Malalantang, M.R. Waani

Fakultas Peternakan Universitas Sam Ratulangi , Manado 95115

\begin{abstract}
ABSTRAK
Penelitian tentang pemberian rumput raja (Pennisetum purpupoides) dan tebon jagung sebagai bahan penyusun ransum telah dilaksanakan untuk mengetahui pengaruhnya terhadap performans sapi peranakan ongole (PO) betina. Penelitian ini menggunakan 15 ekor sapi PO betina dengan umur \pm 2 tahun dengan berat badan $\pm 200 \mathrm{~kg}$. Rancangan yang digunakan adalah Rancangan Acak Lengkap (RAL) yang terdiri dari 5 perlakuan dan 3 ulangan. Perlakuan tersebut adalah perbandingan antara rumput raja dan tebon jagung, yaitu R1 $=100 \%$ rumput raja, $\mathrm{R} 2=75 \%$ rumput raja + $25 \%$ tebon jagung, $\mathrm{R} 3=50 \%$ rumput raja $+50 \%$ tebon jagung, $\mathrm{R} 4=25 \%$ rumput raja $+75 \%$ tebon jagung, dan $\mathrm{R} 5=100 \%$ tebon jagung. Variabel yang diukur guna melihat respons biologis sapi PO terhadap pemberian rumput raja dan tebon jagung yaitu konsumsi bahan kering (BK) ransum, pertambahan bobot badan, dan konversi ransum. Konsumsi BK ransum, $\mathrm{PBBH}$ dan konversi ransum pada penelitian ini secara berturutturut berkisar antara 4,64 - 5,97 $\mathrm{kg}$ /ekor/hari, 0,36-0,55 kg/ekor/hari dan $10,89-13,44$.
\end{abstract}

*Korespondensi (correspondence)

Email : zhang_heryanto@yahoo.co.id
Hasil analisis keragaman menunjukkan bahwa perlakuan memberikan pengaruh yang berbeda sangat nyata $(\mathrm{P}<0,05)$ terhadap konsumsi BK ransum dan pertambahan bobot badan, tetapi pengaruh yang tidak berbeda nyata $(\mathrm{P}>0,05)$ terhadap konversi ransum. Hasil uji lanjut Tukey menunjukkan konsumsi BK ransum perlakuan R2, $\mathrm{R} 3$, dan R4 tidak berbeda nyata $(\mathrm{P}>0,05)$, tetapi $\mathrm{R} 1$ dan $\mathrm{R} 2$ nyata lebih rendah $(\mathrm{P}<0,05)$ dibandingkan dengan R5, sedangkan R3, R4, dan R5 tidak berbeda nyata $(\mathrm{P}>0,05)$. Pertambahan bobot badan R1 tidak berbeda nyata $(\mathrm{P}<0,05)$ dengan $\mathrm{R} 2$, $\mathrm{R} 3$, dan R4 tetapi nyata lebih rendah dibandingkan dengan R5. Berdasarkan hasil konsumsi BK, $\mathrm{PBBH}$, dan konversi ransum maka dapat disimpulkan bahwa pemberian rumput raja dalam ransum maksimal $50 \%$ dan tebon jagung minimal $50 \%$ memberikan performans yang baik pada sapi $\mathrm{PO}$ betina.

Kata Kunci : Rumput raja (Pennisetum purpupoides), tebon jagung, performans sapi PO betina. 


\section{ABSTRACT}

THE EFFECTS OF AFFERING KING GRASS (Pennisetum Purpupoides) AND CORN STOVER ON PERFORMANCE OF ONGOLE CROSSBREED COWS A research evaluating the effects of affering king grass (Pennisetum purpupoides) and corn stover as feed ingredients on performance of ongole crossbreed cows has been conducled. Two years old, of fifteen ongole crossbreed cows with $\pm 200 \mathrm{~kg}$ body weight were used in this experiment. Completely Randomized Design with 5 treatments and 3 replications was used. The treatments were $\mathrm{R} 1=$ $100 \%$ king grass, $\mathrm{R} 2=75 \%$ king grass $+25 \%$ corn stover, $\mathrm{R} 3=50 \%$ king grass $+50 \%$ corn stover, $\mathrm{R} 4=$ $25 \%$ king grass $+75 \%$ corn stover and R5 $=100 \%$ corn stover. Variables measured were dry matter consumption (DMC), average daily gain (ADG) and feed conversion (FC). The average of DMC, ADG and $\mathrm{FC}$ were $4,64-5,97 \mathrm{~kg} /$ tail/day, $0,36-0,55 \mathrm{~kg} / \mathrm{tail} / \mathrm{day}$ and 10,89 13,44 respectively. The results showed that there were significant effects $(\mathrm{P}<0,05)$ on DMC and ADG, however, there was no significant effect $(\mathrm{P}>0,05)$ on FC. Tukey test showed that DMC of cows fed R1 were significantly $(\mathrm{P}<0,05)$ lower compared to R5, however, there was no significant $(\mathrm{P}>0,05)$ difference among cows fed R3, R4 and R5. ADG of cows fed R1 was not significantly $\quad(\mathrm{P}>0,05) \quad$ different compared to R2, R3 and R4, while, cows fed R1 and R2 were Significantly $\quad(\mathrm{P}<0,05) \quad$ lower compared to R5. Based on the results on $\mathrm{DMC}, \mathrm{ADG}$ and $\mathrm{FC}$ it can be concluded that to increase performance of crossbreed cows the portion of king grass can be affered up to $50 \%$, on the other hand corn stover is more than $50 \%$ in the ration.

Key words : Kinggrass

(Pennisetum purpupoides), corn stover, performance ongole crossbreed cows.

\section{PENDAHULUAN}

Seiring dengan meningkatnya jumlah penduduk, tingkat kesejahteraan dan tingkat pendidikan, maka kebutuhan daging masyarakat juga semakin meningkat. Sapi potong merupakan salah satu sumber penghasil daging yang potensial, memiliki nilai gizi tinggi dan sangat bermanfaat bagi masyarakat. Salah satu jenis sapi potong yang dapat digunakan sebagai bakalan dalam usaha penggemukan sapi potong adalah sapi Peranakan Ongole (PO).

Pakan merupakan salah satu faktor yang sangat penting dalam suatu usaha penggemukan sapi potong. Rumput raja (Pennisetum purpupoides) dan tebon jagung merupakan hijauan yang sering diberikan pada sapi potong. Produksi rumput raja cukup tinggi dibandingkan dengan rumput lainnya yaitu 1076 Ton/ha/tahun (Siregar, 
1994). Rumput raja mempunyai kandungan SK 25,48, protein kasar (PK) $11,68 \%$, Ca 0,37\% dan P 0,39\% (Rumiyati, 2008).Tebon jagung merupakan hasil ikutan atau limbah tanaman jagung berupa batang dan daun setelah diambil buahnya yang masih muda. Tebon jagung mempunyai kandungan kadar protein sekitar $12,06 \%$, serat kasar 25,20\%, dan energi metabolisme $2350 \mathrm{kkal} / \mathrm{kg}$ (Erna dan Sarjiman, 2007).

Berdasarkan hal tersebut diatas maka telah dilakukan suatu penelitian yang bertujuan untuk mengevaluasi pemberian rumput raja dan tebon jagung terhadap performans sapi PO.

\section{MATERI DAN METODE PENELITIAN}

Penelitian ini dilaksanakan di Balai Pembibitan Ternak
DesaTampusu Kec. Remboken dari tanggal 24 Mei sampai dengan tanggal 29 juli 2015. Tahap adaptasi 5 hari dan tahap pengambilan data 60 hari.

Ternak yang digunakan dalam penelitian ini adalah ternak sapi PO betina sebayak 15 ekor dengan berat badan $\pm 200 \mathrm{~kg}$. Kandang yang digunakan adalah kandang individual sebanyak 15 kandang yang di lengkapi dengan tempat pakan dan tempat minum. Perlengkapan lain yang digunakan dalam penelitian ini yaitu timbangan digital untuk menimbang pakan dan timbangan ternak.

Pakan yang digunakan adalah rumput raja, tebon jagung, dan dedak padi. Komposisi zat makanan dari semua bahan pakan yang digunakan dapat dilihat pada tabel berikut ini.

Tabel 1. Komposisi Zat-zat Makanan Bahan Pakan (Dasar Bahan Kering)

\begin{tabular}{lcc}
\hline Zat - zat makanan & \multicolumn{2}{c}{ Bahan Pakan } \\
\cline { 2 - 3 } & Rumput Raja* & Tebon Jagung** \\
\hline Protein Kasar (\%) & 11,68 & 12,06 \\
Serat Kasar (\%) & 25,48 & 25,2 \\
Ca (\%) & 0,37 & 0,28 \\
$\mathrm{P}(\%)$ & 0,35 & 0,23 \\
Energi Metabolisme & 2070 & 2350 \\
(kkal/kg) & & \\
Sumber : *) Rumiyati, 2008 & \\
*) Erna dan Sarjiman, 2007
\end{tabular}


Tabel 2. Formulasi Pakan Perlakuan dan Komposisi Zat-Zat Makanan (Dasar Bahan Kering)

\begin{tabular}{lccccc}
\hline \multirow{2}{*}{ Bahan Pakan } & \multicolumn{5}{c}{ Perlakuan } \\
\cline { 2 - 6 } & R1 & R2 & R3 & R4 & R5 \\
\hline Rumput raja (\%) & 100 & 75 & 50 & 25 & 0 \\
Hijauan jagung (\%) & 0 & 25 & 50 & 75 & 100 \\
Total & 100 & 100 & 100 & 100 & 100 \\
Komposisi Zat Makanan (\%) & & & & & \\
Protein kasar & 11,68 & 11,77 & 11,87 & 11,96 & 12,06 \\
Serat kasar & 25,48 & 25,41 & 25,34 & 25,27 & 25,2 \\
Ca & 0,37 & 0,35 & 0,32 & 0,30 & 0,28 \\
P & 0,35 & 0,32 & 0,29 & 0,26 & 0,23 \\
Energi & 2070 & 2140 & 2210 & 2280 & 2350 \\
(kkal/kg) & & & & & \\
\hline Ket & Metabolisme & & &
\end{tabular}

Ket : Dihitung berdasarkan Tabel 1.

Penelitian ini merupakan penelitian eksperimental dengan menggunakan Rancangan Acak Lengkap ( Steel and Torrie, 1995) yang terdiri dari 5 perlakuan dan 3 ulangan. Respon sapi PO terhadap penggunaan rumput raja dan tebon jagung diukur melalui :

1. Konsumsi ransum (Kg/ekor/hari) diperoleh dari selisih antara jumlah pakan yang diberikan dengan pakan sisa setiap harinya selama penelitian.

2. Pertambahan bobot badan (Kg/ekor/hari) diperoleh dari selisih antara bobot akhir dengan bobot badan awal selama penelitian.

3. Konversi ransum yaitu, perbandingan antara konsums BK pakan dengan pertambahan bobot badan selama periode penelitian.

\section{HASIL DAN PEMBAHASAN}

Data hasil penelitian tentang pemberian rumput raja (Pennisetum purpupoides) dan tebon jagung terhadap konsumsi BK ransum, pertambahan bobot badan, dan konversi ransum dapat dilihat pada Tabel 3.

Tabel 3. Rerata Konsumsi BK Ransum, Pertambahan Bobot Badan, dan Konversi Ransum Sapi PO yang diberi Rumput Raja dan Tebon Jagung.

\begin{tabular}{lcrrrr}
\hline \multicolumn{1}{c}{ Parameter } & \multicolumn{5}{c}{ Perlakuan } \\
\cline { 2 - 6 } & $\mathrm{R}_{1}$ & $\mathrm{R}_{2}$ & $\mathrm{R}_{3}$ & $\mathrm{R}_{4}$ & $\mathrm{R}_{5}$ \\
\hline $\begin{array}{l}\text { Konsumsi Ransum } \\
\left(\text { Kg.ekor }^{-1} \text { hari }^{-1}\right)\end{array}$ & $4,64^{\mathrm{a}}$ & $5,32^{\mathrm{b}}$ & $5,71^{\mathrm{bc}}$ & $5,72^{\mathrm{bc}}$ & $5,97^{\mathrm{c}}$ \\
$\begin{array}{l}\text { Pertambahan Bobot Badan } \\
\left(\text { Kg.ekor }^{-1} \text { hari }^{-1}\right)\end{array}$ & $0,36^{\mathrm{a}}$ & $0,40^{\mathrm{a}}$ & $0,46^{\mathrm{ab}}$ & $0,46^{\mathrm{ab}}$ & $0,55^{\mathrm{b}}$ \\
Konversi Ransum & 13,01 & 13,44 & 12,51 & 12,35 & 10,89 \\
\hline
\end{tabular}

Keterangan: Superskrip berbeda pada baris yang sama menunjukkan perbedaan yang nyata $(\mathrm{P}<0,05)$ 


\section{Konsumsi Bahan Kering Ransum}

Jumlah konsumsi pakan merupakan faktor penentu yang paling penting dalam menentukan jumlah nutrien yang didapat oleh ternak dan selanjutnya mempengaruhi tingkat produksi. Konsumsi pakan pada ternak ruminansia sangat kompleks dan banyak faktor yang menentukan, seperti faktor pakan, ternak dan lingkungan (Wodzicka dkk. 1993). Rerata konsumsi BK ransum sapi PO selama penelitian untuk masing-masing perlakuan R1, R2, R3, R4 dan R5 berkisar antara 4,64 - 5,97 kg/ekor/hari (Tabel 3). Kisaran rerata konsumsi BK pada penelitian ini sesuai dengan rerata konsumsi BK pakan yang dinyatakan oleh Widya dkk. (2008) bahwa konsumsi BK sapi PO dengan bobot badan $\pm 200 \mathrm{~kg}$ adalah $5,14-5,55 \mathrm{~kg} / \mathrm{ekor} / \mathrm{hari}$. Hasil analisis varians menunjukkan bahwa pemberian rumput raja dan tebon jagung dengan level yang berbeda memberikan pengaruh yang berbeda sangat nyata $(\mathrm{P}<0,05)$ terhadap konsumsi BK.

$$
\text { Hasil uji lanjut Tukey }
$$
menunjukkan bahwa konsumsi BK ransum perlakuan R2, R3, dan R4 tidak berbeda nyata $(\mathrm{P}>0,05)$, tetapi $\mathrm{R} 2$ nyata lebih rendah $(\mathrm{P}<0,05)$ dibandingkan dengan $\mathrm{R} 5$, sedangkan R3, R4, dan R5 tidak berbeda nyata $(\mathrm{P}>0,05)$. Tigginya konsumsi $\mathrm{BK}$ pada R3, R4 dan R5 diduga bawha tebon jagung tang rasanya lebih manis dibandingkan rumput raja sehingga lebih palatable, hal ini menyebabkan ransum yang mengandung lebih tinggi level tebon jagung dikonsumsi lebih banyak. Dari hasil pengamatan selama penelitian ternak lebih memilih tebon jagung daripada rumput raja untuk dikonsumsi lebih dahulu. Menurut Kartadisastra (1997) Tinggi rendahnya konsumsi dipengaruhi juga oleh palatabilitas, konsentrasi nutrisi dan bentuk pakan. Palatabilitas merupakan sifat performansi bahan-bahan pakan sebagai akibat dari keadaan fisik dan kimiawi bahan-bahan pakan yang dicerminkan oleh bau, rasa dan tekstur. Hal inilah yang menimbulkan daya tarik dan merangsang ternak sehingga mempengaruhi tingkat konsumsi.

\section{Pertambahan Bobot Badan}

Pertambahan bobot badan merupakan ekpresi dari konsumsi zat-zat makanan dan ada kaitannya juga dengan kecernaan zat-zat makanan (Wardhani dan Mosafie, 1991). Rerata pertambahan bobot badan harian (PBBH) sapi PO selama penelitian masing-masing perlakuan R1, R2, R3, R4, dan R5 berkisar antara 0,36 - 0,55 kg/ekor/hari (Tabel 3). Menurut Williamson dan Payne (1987) pertambahan bobot badan pada sapi PO mencapai $0,5 \mathrm{~kg} / \mathrm{ekor} / \mathrm{hari}$ jika diberikan pakan yang baik. Hasil analisis varian menunjukkan bahwa pemberian rumput 
raja dan tebon jagung memberikan pengaruh yang berbeda sangat nyata $(\mathrm{P}>0,01)$ terhadap PBBH. Uji lanjut Tukey menunjukkan bahwa pertambahan bobot badan $\mathrm{R} 1$ berbeda tidak nyata $(\mathrm{P}<0,05)$ dengan R2, R3, dan R4 tetapi nyata lebih rendah $(\mathrm{P}>0,05)$ dibandingkan dengan $\mathrm{R}_{5}$. Menurut Zulbardi dkk. (2001), konsumsi suatu bahan pakan berpengaruh terhadap pertambahan bobot badan ternak. Tillman dkk. (1991) menyatakan bahwa semakin tinggi konsumsi bahan kering, maka akan semakin banyak zat-zat makanan yang dikonsumsi yang akan digunakan untuk pertumbuhan dan produksi sehingga berpengaruh pada bobot badan.

Protein merupakan salah satu komponen nutrien pakan yang penting untuk pertumbuhan ternak. Tingginya pertambahan bobot badan sapi berbanding lurus dengan kandungan protein kasar dalam ransum yang dikonsumsi (Martawidjaja, 1998). Kandungan protein kasar dalam ransum penelitian ini berkisar $11,68 \%$ - 12,06 \% mampu memberikan pengaruh yang nyata terhadap $\mathrm{PBBH}$. Hasil ini sejalan dengan yang dilaporkan Agus wijaya (2008) yang menggunakan ransum penelitian dengan kandungan protein kasar berkisar 11,50 \% - 12,56 \% dimana ransum dengan kandungan protein lebih tinggi menghasilkan $\mathrm{PBBH}$ yang lebih baik.

\section{Konversi Ransum}

Konversi ransum merupakan perbandingan antara konsumsi BK ransum dengan pertambaha bobot badan. Konversi pakan digunakan sebagai tolak ukur efisiensi produksi, semakin rendah nilai konversi berarti efisiensi penggunaan pakan semakin tinggi (Siregar,1994). Menurut Martawidjaja (1998), konversi pakan dipengaruhi oleh kualitas pakan, pertambahan bobot badan dan kecernaan, yang artinya semakin baik kualitas pakan yang dikonsumsi akan menghasilkan pertambahan bobot badan yang lebih tinggi dan lebih efisien penggunaan pakannya. Rerata konversi ransum sapi PO selama penelit ian untuk masing-masing perlakuan R1, R2, R3.R4 dan R5 berkisar antara 10,89 - 13,44 (Tabel 3). Hasil penelitian ini memiliki konversi ransum yang lebih baik dibandingkan dengan hasil penelitian Astutik dkk. (2002) pada sapi PO yang diberikan pakan jerami padi yang menghasilkan konversi pakan berkisar 14,18. Hasil analisis varians menunjukkan bahwa pengaruh penggunaan kelima macam perlakuan memberikan pengaruh yang berbeda tidak nyata $(\mathrm{P}>0,05)$.

\section{KESIMPULAN}

Berdasarkan hasil konsumsi BK, PBBH, dan konversi ransum maka dapat disimpulkan bahwa pemberian rumput raja 
dalam ransum maksimal $50 \%$ dan tebon jagung minimal $50 \%$ memberikan performans yang baik pada sapi PO betina.

\section{DAFTAR PUSTAKA}

Agus, W. 2008. Pengaruh Imbangan Hijauan dengan Konsentrat Berbahan Baku Limbah Pengolahan Hasil Pertanian Dalam Ransum Terhadap Penampilan Sapi PFH Jantan. Sains Peternakan Jurnal Penelitian Ilmu Peternakan. Fakultas Pertanian Vol. 9 : 48-54.

Astutik, S.I., M. Arifin dan W. S. Dilaga. 2002. Respon Produksi Sapi Peranakan Ongole Berbasis Pakan Jerami Padi Terhadap Formula Urea Molasse Block. Jurnal Ilmu Ternak dan Veteriner. Vol. 5 : 82-87.

Erna, W. dan Sarjiman, 2007. Budidaya Hijauan Pakan Bersama Tanaman Pangan Sebagai Upaya Penyediaan Hijauan Pakan di Lahan Sempit. Jurnal Peternakan dan Lingkungan. Vol 7 : 134-141.

Kartadisastra, H.R. 1997. Penyediaan dan Pengelolaan Pakan Ternak Ruminansia. Kanisius.

Yogyakarta.

Martawidjaja, M. 1998. Pengaruh Taraf Pemberian Konsentrat Terhadap Keragaman Kambing Kacang Betina Sapihan. Jurnal Ilmu Ternak dan Veteriner. Vol 4 : 93-99.

Rumiyati. 2008. Pengaruh Imbangan Jerami Kacang Tanah Dengan Rumput Raja Dalam Ransum Terhadap Performan Sapi PFH jantan. Jurnal Penelitian Ilmu
Peternakan. Fakultas Pertanian. Vol $9: 62-68$.

Siregar, S.B. 1994. Ransum Ternak Ruminansia. Penebar Swadaya. Jakarta.

Steel, R.C. dan Torrie J.H. 1995. Prinsip dan Prosedur Statistika. Gramedia Pusaka Utama. Jakarta.

Tillman, A.D., H.Hartadi, S Reksohadiprodjo, S. Prawirokusomo dan S. Lebdosoekejo. 1991. Ilmu Makanan Ternak Dasar. Gadjah Mada Universitas Press. Yogyakarta.

Wardhani, N. K dan A. Mosafie. 1991. Jerami Jagung Segar, Kering dan Teramoniasi sebagaiPengganti Hijauan Sapi Potong. Jurnal Ilmiah Penelitian Ternak Gratis. Vol 2 : 12-19.

Widya, P.L., Waluyo, E.S., dan A.B. Yuliato. 2008. Konsumsi dan Kecernaan Bahan Kering dan Bahan Organik Dalam Haylase Pakan Lengkap Ternak Sapi Peranakan Ongole. Jurnal Ilmu Peternakan dan Veteriner. Fakultas Kedokteran Hewan. Vol 8 : 25-32.

Williamson, G. dan J.A. Payne. 1987. An Introduction to Animal Husbandry in The Tropics. Longman Group. London. Dalam Darmadja, D. (edt). 1993. Pengantar Peternakan di Daerah Tropis. Gadjah Mada University Press, Yogyakarta.

Wodzicka, M. Tomaszewska, A. Djajanegara, S. Gardiner, T.R. Wiradarya dan I.M. Mastika. 1993. Produksi Kambing dan Domba di Indonesia. Penerjemah I.M. Mastika, K.G. 
Jurnal Zootek (“Zootek” Journal) Vol. 36 No. 1 : 123-130 (Januari 2016) ISSN 0852 -2626

Suryana, I.G. Lanang Oka dan I.B. Sutrisna. Universitas Sebelas Maret Press. Surakarta.

Zulbardi, M., A.A. Karto, U. Kusnadi dan A. Thalib. 2001. Pemanfaatan Jerami Padi bagi Usaha Sapi Peranakan Ongole di Daerah
Irigasi Tanaman Padi. Jurnal Ilmu Peternakan dan Veteriner. Vol 3 : 256261. 